\title{
Polycondensation of Tetrahydrofuran with Phthalic Anhydride Induced By a Proton Exchanged Montmorillonite Clay
}

\author{
Mohammed Issam Ferrahi, Mohammed Belbachir \\ Laboratoire de Chimie des Polymères, Département de Chimie, Faculté des Sciences, \\ Université d'Oran Es-Sènia BP N 1524 El M'Naouar, 31000, Oran, ALGERIE. \\ Fax: 0021341416021; E-mail: mohammed.ferrahi@caramail.com
}

Received: 1 February 2003 / Accepted: 5 March 2003 / Published: 31 May 2003

\begin{abstract}
Maghnite" a montmorillonite sheet silicate clay, exchanged with protons to produce "H-Maghnite" is an efficient catalyst for polymerization of many vinylic and heterocyclic monomers (Belbachir, M. U.S. Patent. 066969.0101 -2001). The structure compositions of both "Maghnite" and "H-Maghnite" have been developed. This catalyst was used for the polycondensation of the tetrahydrofuran with phthalic anhydride. The polymerization was performed under suitable conditions at temperature $\left(40^{\circ} \mathrm{C}\right)$, in presence of acetic anhydride. Experiments revealed that polymerization induced by "H-Maghnite", proceed in bulk and the conversion increases with increasing "H-Maghnite" proportion.
\end{abstract}

Keywords: Anhydride, Maghnite, Montmorillonite, Phthalic, Tetrahydrofuran.

\section{Introduction}

The use of acid treated clays as a solid source of protons in a number of industrial significant reactions continue because they constitute a widely available, inexpensive solid source of protons, e.g. they were employed as cracking catalysts until the 1960s [1] and are still currently used in industrial processes such as the alkylation of phenols [2] and the dimerization and polymerization of unsaturated hydrocarbons [3].

Montmorillonites have both Brönsted and Lewis acid sites and when exchanged with cations having a high charges density, as protons, produce highly-active catalysts for acid-catalysed reactions [4]. Intercalated organic molecules are mobile and can be highly polarized when situated in the space 
between the charged clay layers. These exchanged montmorillonites have been successfully used as catalysts for the reactions of polymerization [3].

The present study shows the synthesis of the poly(oxybutylene oxyphthaloyl), whose the structure differs from that of the poly (butylene terephthalate) by the position of the substituents, the first has a 1,2 substitution pattern and the second has a 1,4.

The Poly(butylene terephthalate) is usually prepared from butan 1,4 diol and terephthalate of dimethyl by reaction of transesterification [5]. One of the biggest problems with this reaction has been that the 1,4-diol under the reaction conditions is converted to tetrahydrofuran, which is a dead-end byproduct. In this respect, it is even more interesting to use tetrahydrofuran as a source of an oxybutylene part in the polymer.

This study is also concerned with polycondensation and examines the catalytic activity of Algerian proton exanged montmorillonite clay called "Maghnite".

The aim of this research is to extend the scope of other promising new field of polymer synthesis by the use of another catalyst system that has been shown to exhibit higher efficiency.

This paper concerns detailed analyses of "raw-Maghnite", "H-Maghnite" and polymerization products, effect of catalyst ration and effect of acetic anhydride proportion upon the conversion.

\section{Experimental}

\section{A. Materials}

1) "H-Maghnite xM": The acid forms of "raw-Maghnite" is prepared by shaking the material raw (raw-Maghnite) with solution of sulfuric acid until saturation achieved over two days at room temperature, washing the mineral with water until sulfate-free and drying. The concentrations $0.05 \mathrm{M}, 0.10 \mathrm{M}, 0.15 \mathrm{M}, 0.20 \mathrm{M}, 0.25 \mathrm{M}, 0.30 \mathrm{M}$ and $0.35 \mathrm{M}$ of sulfuric acid treatment solutions were used to prepare "H-Maghnite0.05M", "H-Maghnite0.10M", "H-Maghnite0.15M" , "HMaghnite0.20M", "H-Maghnite0.25M", "H-Maghnite0.30M" and "H-Maghnite0.35M" respectively.

2) Tetrahydrofuran (THF 99\%) was used as received.

3) Phthalic anhydride (98\%) was used as received.

4) Acetic anhydride (98\%) was used as received.

5) Ethanol (98\%) was used as received.

\section{B. "Maghnite" and "H-Maghnite" characterization}

1) Samples for XRF analysis were prepared using the $\mathrm{LiB}_{4} \mathrm{O}_{7}$ fusion method. The resulting beads were analyzed on a Philips PW 2400XRF spectrometer in Laboratory of Inorganic Chemistry, Granada University, Spain. 
2) XRD profiles for pressed powder samples were recorded on a Philips PW 1710 diffractometer using $\mathrm{Cu}-\mathrm{Ka}$ radiation $(v=1.5418 \AA)$.

3) IR absorption spectra were recorded on a ATI Matson FTIR N9501165 spectrometer using the $\mathrm{KBr}$ pressed-disc technique, $0.5 \mathrm{mg}$ of sample was added to $300 \mathrm{mg} \mathrm{KBr}$ and mixed for $3 \mathrm{~min}$ in a vibratory grinder prior to pressing a $13 \mathrm{~mm}$ disc.

4) High-resolution solid-state ${ }^{29} \mathrm{Si}$ and ${ }^{27} \mathrm{Al}$ MAS NMR spectra of untreated (raw-Maghnite) and acid treated (H-Maghnite0.25M) samples were recorded on a Brüker ASX 500 spectrometer at 59.6 and $130.3 \mathrm{MHz}$ respectively. The sample spinning frequency was $4 \mathrm{KHz}$ for ${ }^{29} \mathrm{Si}$ and $11.5 \mathrm{KHz}$ for ${ }^{27} \mathrm{Al}$.

\section{Procedure and polymer characterization}

Polymerizations were carried out in stirred flasks at $40^{\circ} \mathrm{C}$. The catalyst was dried in a muffle at $120^{\circ} \mathrm{C}$ over night and then transferred to a vacuum desiccator containing $\mathrm{P}_{2} \mathrm{O}_{5}$. After cooling to room temperature under vacum, the mineral was added to the Tetrahydrofuran $(10.75 \mathrm{~mol} / \mathrm{l})$, Phthalic anhydride $(5.67 \mathrm{~mol} / \mathrm{l})$ and Acetic anhydride(1.28mol/l) mixture preliminary keeped in stirred flask at $40^{\circ} \mathrm{C}$. At the required time, an aliquot of the reaction mixture was then taken in such manner as to exclude any clay mineral and slowly added to ethanol with stirring. The precipitated polymer was filtred off and dried under vacuum and weighed. The polymers were redissolved in THF and precipitated into ethanol for characterization and molecular weight measurement.

Molecular weights were determined by a Waters high pressure GPC instrument (Model 6000A Pump) having a serie of ultra-Styragel columns (100, 500, 103, 104, $105 \AA$ A), a Differential Refractometer 2401 and a UV absorbance Detector Model 440. The flow rate of tetrahydrofuran (THF) was $1 \mathrm{ml} / \mathrm{min}$. The calibration curve was made with well-fractionated PBT standards.

${ }^{1} \mathrm{H}$ NMR spectra were recorded on an AM 300 FT Bruker instrument using deuterated THF as solvent, and tetramethylsilane (TMS) as internal standard.

\section{Results and Discussion}

\section{Catalyst structure}

Various methods of analysis, such as ${ }^{27} \mathrm{Al}$ and ${ }^{29} \mathrm{Si}$ MAS NMR, show that "Maghnite" is a montmorillonite sheet silicate clay. The elementary analysis of the selected samples obtained using XRF and conversions obtained from the reaction of $1 \mathrm{~g}$ of each sample with $10.75 \mathrm{~mol} / \mathrm{l}$ of THF, 5.67 $\mathrm{mol} / \mathrm{l}$ of phthalic anhydride and $1.28 \mathrm{~mol} / \mathrm{l}$ of acetic anhydride during 6 hours in a bulk polymerization at $40^{\circ} \mathrm{C}$, are as settled in the following Table 1.

It is necessary to report that the best value of conversion was obtained with "HMaghnite0.25M", for this reason we kept this sample to study the effect of catalyst and acetic anhydride proportions on 
Table 1. Elementary compositions of Protons exchanged samples "H-Maghnite"

\begin{tabular}{|c|c|c|c|c|c|c|c|c|c|c|c|c|}
\hline \multirow[b]{2}{*}{ sample } & \multicolumn{11}{|c|}{ Compositions wt $\%$} & \multirow{2}{*}{$\begin{array}{l}\text { conver- } \\
\text { sion } \%\end{array}$} \\
\hline & $\overline{\mathrm{SiO}_{2}}$ & $\mathrm{Al}_{2} \mathrm{O}_{3}$ & $\mathrm{Fe}_{2} \mathrm{O}_{3}$ & $\mathrm{CaO}$ & $\mathrm{MgO}$ & $\mathrm{Na}_{2} \mathrm{O}$ & $\mathrm{K}_{2} \mathrm{O}$ & $\mathrm{TiO}_{2}$ & $\mathrm{SO}_{3}$ & As & $\mathrm{PF}^{*}$ & \\
\hline Raw-Maghnite & 69.39 & 14.67 & 1.16 & 0.30 & 1.07 & 0.50 & 0.79 & 0.16 & 0.91 & 0.05 & 11.0 & 0.0 \\
\hline H-Mag0.05M & 70.75 & 14.67 & 1.05 & 0.30 & 1.01 & 0.49 & 0.78 & 0.16 & 0.75 & 0.04 & 10.0 & 1.0 \\
\hline H-Mag0.10M & 71.00 & 14.60 & 1.00 & 0.30 & 0.98 & 0.39 & 0.78 & 0.16 & 0.55 & 0.04 & 10.2 & 2.51 \\
\hline H-Mag0.15M & 71.58 & 14.45 & 0.95 & 0.29 & 0.91 & 0.35 & 0.77 & 0.15 & 0.42 & 0.03 & 10.1 & 9.38 \\
\hline H-Mag0.20M & 71.65 & 14.20 & 0.80 & 0.28 & 0.85 & 0.30 & 0.77 & 0.15 & 0.39 & 0.01 & 10.6 & 12.27 \\
\hline H-Mag0.25M & 71.70 & 14.03 & 0.71 & 0.28 & 0.80 & 0.21 & 0.77 & 0.15 & 0.34 & 0.01 & 11.0 & 28.32 \\
\hline H-Mag0.30M & 73.20 & 13.85 & 0.70 & 0.27 & 0.78 & 0.20 & 0.76 & 0.13 & 0.31 & 0.02 & 9.78 & 20.57 \\
\hline H-Mag0.35M & 75.31 & 13.52 & 0.71 & 0.26 & 0.78 & 0.18 & 0.75 & 0.13 & 0.32 & 0.01 & 8.03 & 17.26 \\
\hline
\end{tabular}

*PF: Pert in Fire

polymerization. Acid treatment of "Raw-Maghnite" cause reduction in octahedral content $\left(\mathrm{Al}_{2} \mathrm{O}_{3}\right)$ resulted in an increase in the proportion of silica $\left(\mathrm{SiO}_{2}\right)$ observed.

The X-Ray powder diffraction profiles (Figure 1 and Table 2) exhibited the presence of other crystalline phases as quartz, feldspath and calcite in "raw-Maghnit" By treatment acid, all trace of calcite was removed in "H-Maghnite".

The increase in basal spacing from $12.5 \AA$ in "raw-Maghnite", characteristic of one water layer between the sheets, to value of $15.02 \AA$ in "H-Maghnite", where there are two interlamellar water layers, subsequent to acid treatment reflects the change in interlayer cation and its associated hydration state [6].

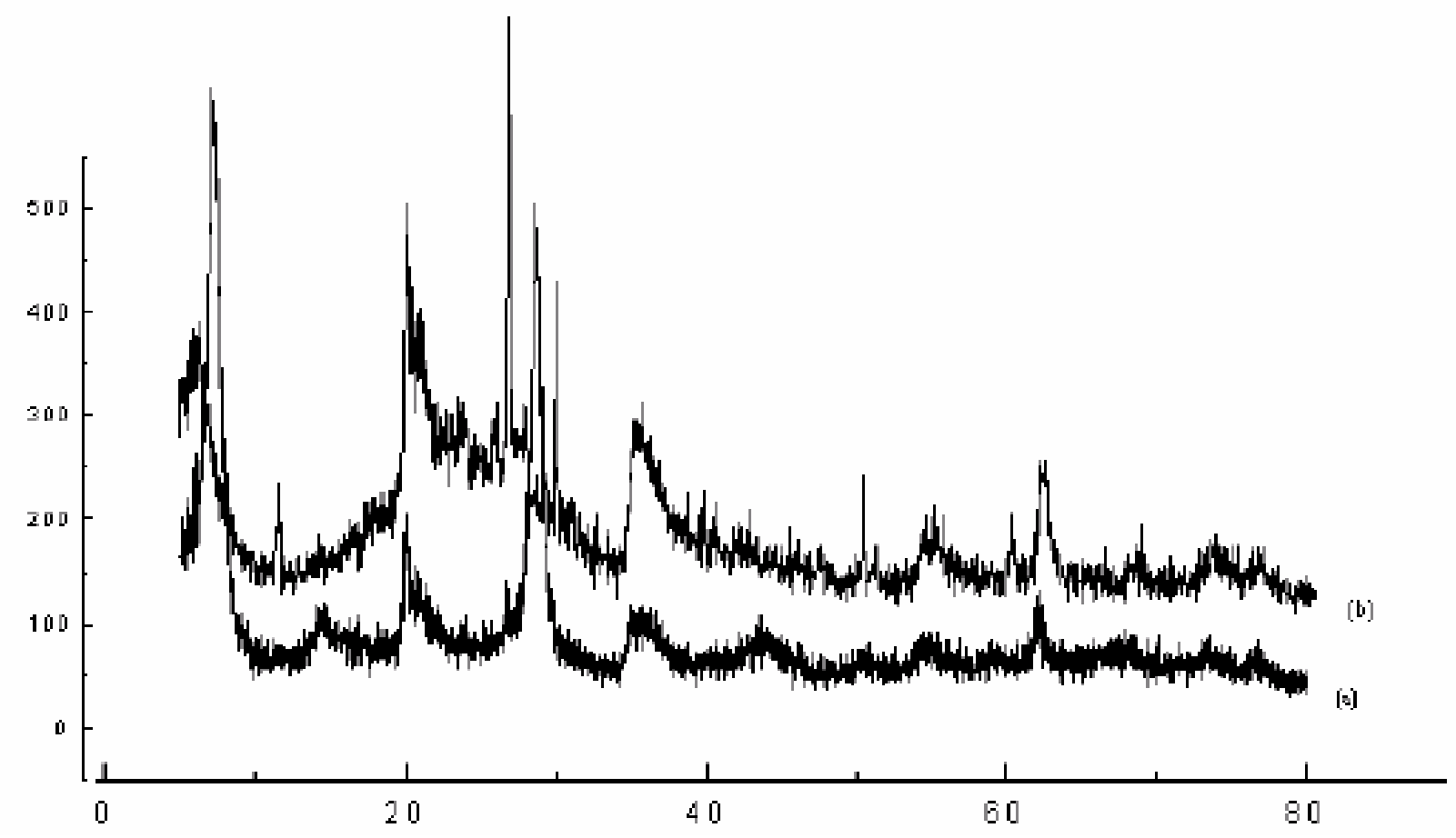

Figure 1. X-ray Power Diffraction of (a) "Raw-Maghnite" and (b) "H-Maghnite 0.25M" 
Table2. RX characteristic of Raw-Maghnite and H-Maghnite $0.25 \mathrm{M}$.

\begin{tabular}{lccl}
\hline Samples & $\mathrm{d}_{\mathrm{hkl}}(\AA)$ & hkl & Naure of samples \\
\hline Raw-Maghnite & 12.50 & 001 & Montmorillonite \\
4.47 & 110 & Montmorillonite \\
4.16 &, & Quartz \\
3.35 &, & Quartz \\
3.21 &, & Feldspath \\
3.03 & 200 & Calcite \\
2.55 & 009 & Montmorillonite \\
1.68 & 060 & Montmorillonite \\
& 1.49 & 001 & Montmorillonite \\
\hline H-Maghnite $0.25 \mathrm{M}$ & 15.02 & 110 & Montmorillonite \\
& 4.47 &, & Montmorillonite \\
& 4.16 &, & Quartz \\
3.35 &, & Quartz \\
& 3.21 &, & Feldspath \\
& 3.03 & Calcite \\
& 2.55 & 000 & Montmorillonite \\
& 1.68 & Montmorillonite \\
& 1.49 & Montmorillonite \\
\hline
\end{tabular}

The IR Spectra of Raw-Maghnite and H-Maghnite 0.25M (Fig. 2) are in good agrement with literature [7]. The characteristic vibrations of hydroxy groups, the silicate anion and the octahedral cations were observed in the IR spectra of both montmorillonites. The most intense band near 1040 Cm-1 is attributed to the Si-O stretching vibrations of the tetrahedral layer and the bands near 522 and $466 \mathrm{Cm}-1$ are assigned to Si-O bending vibrations of smectites. A low intensity band near $800 \mathrm{Cm}-1$, assigned to four-coordinated silica [8], indicates the presence of amorphous silica. Comparison of Raw-Maghnite and H-Maghnite $0.25 \mathrm{M}$ spectra show a small increasing in the $\mathrm{SiO}_{2}$ band intensity near $800 \mathrm{Cm}-1$ in H-Maghnite $0.25 \mathrm{M}$, reflects alterations in the amount of amorphous silica [9].

The ${ }^{27} \mathrm{Al}$ MAS NMR spectra of both Raw-Maghnite and H-Maghnite 0.25M (Fig. 3) show Aluminium in two tetrahedral environments with resonances centered at 60 and $68 \mathrm{ppm}$, in addition to the main contribution from the octahedral aluminium at $2.9 \mathrm{ppm}$. These values and assignments concur with those published in literature [6,10,11].

The ${ }^{29} \mathrm{Si}$ MAS NMR spectra for the Raw-Maghnite and H-Maghnite 0.25M are shown in Fig. 4. The dominant resonance at - $93.5 \mathrm{ppm}$ corresponds to $\mathrm{Q}^{3}(\mathrm{OAl})$ units, i.e $\mathrm{SiO}_{4}$ groups crosslinked in the tetrahedral sheets with no aluminium in the neighbouring tetrahedral [12]. The resonance at -112 ppm corresponds to three-dimensional (3D) silica with no aluminium present, designed $\mathrm{Q}^{4}$ (OAl) $[6,13]$. 

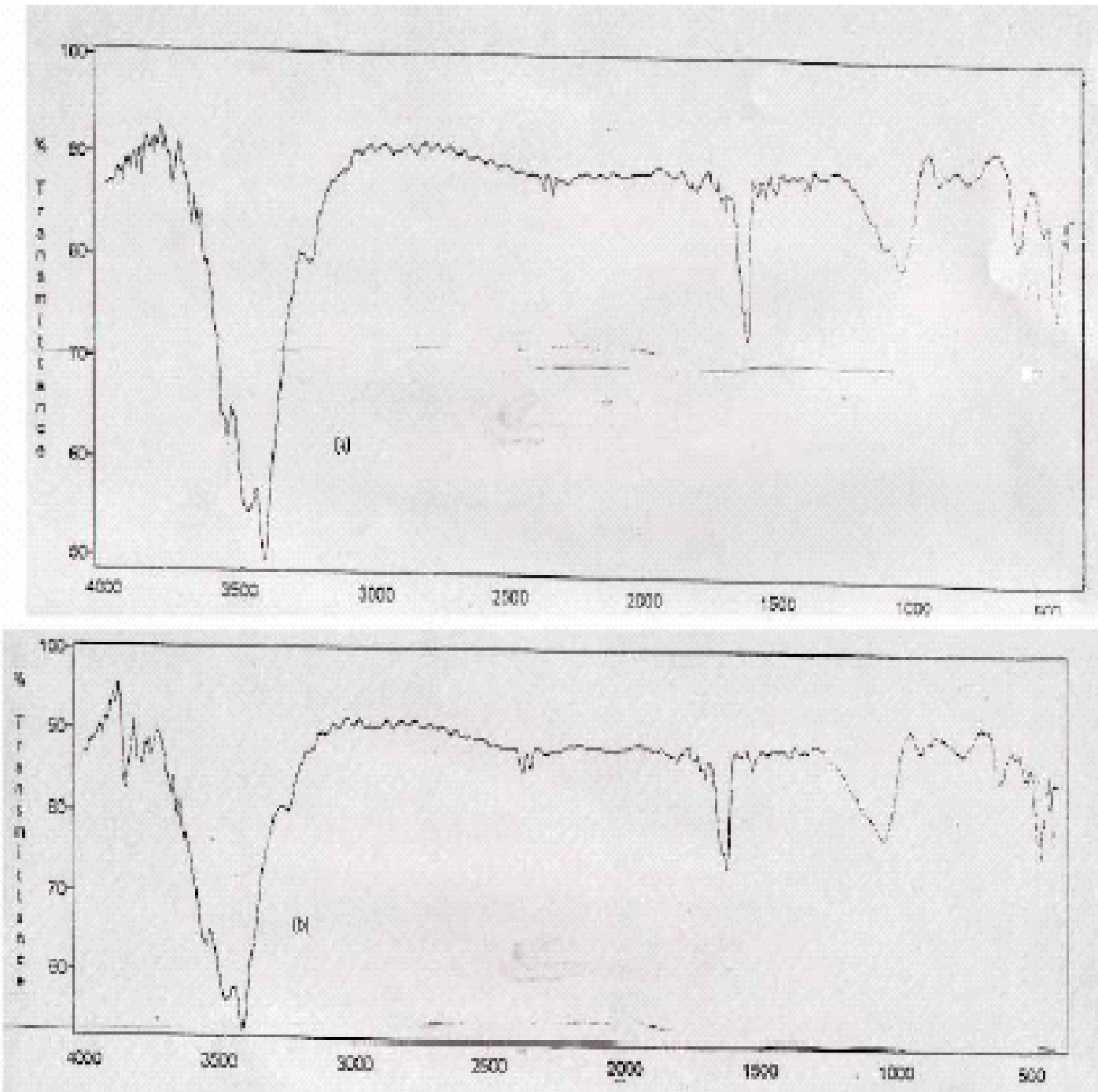

Figure 2. IR Spectra of (a) untreated Clay "Raw-Maghnite" and (b) Acid treated Clay "H-Maghnite0.25M"

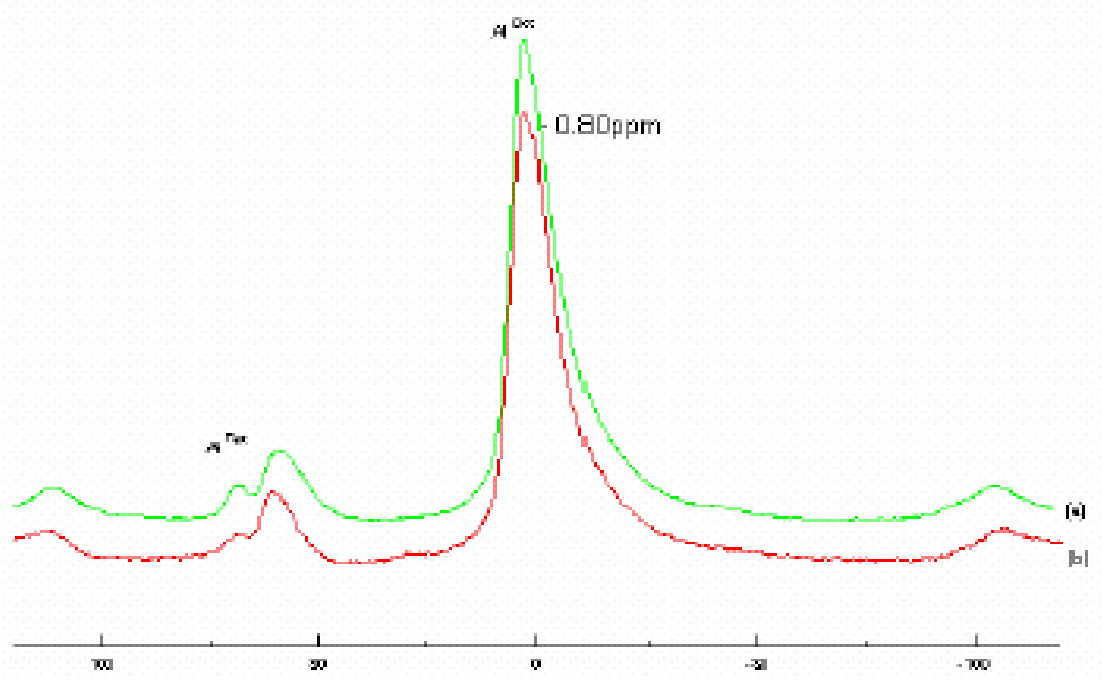

Figure 3. ${ }^{27} \mathrm{Al}$ MAS NMR spectra of (a) "Raw-Maghnite" and (b) "H-Maghnite $0.25 \mathrm{M}$ " 


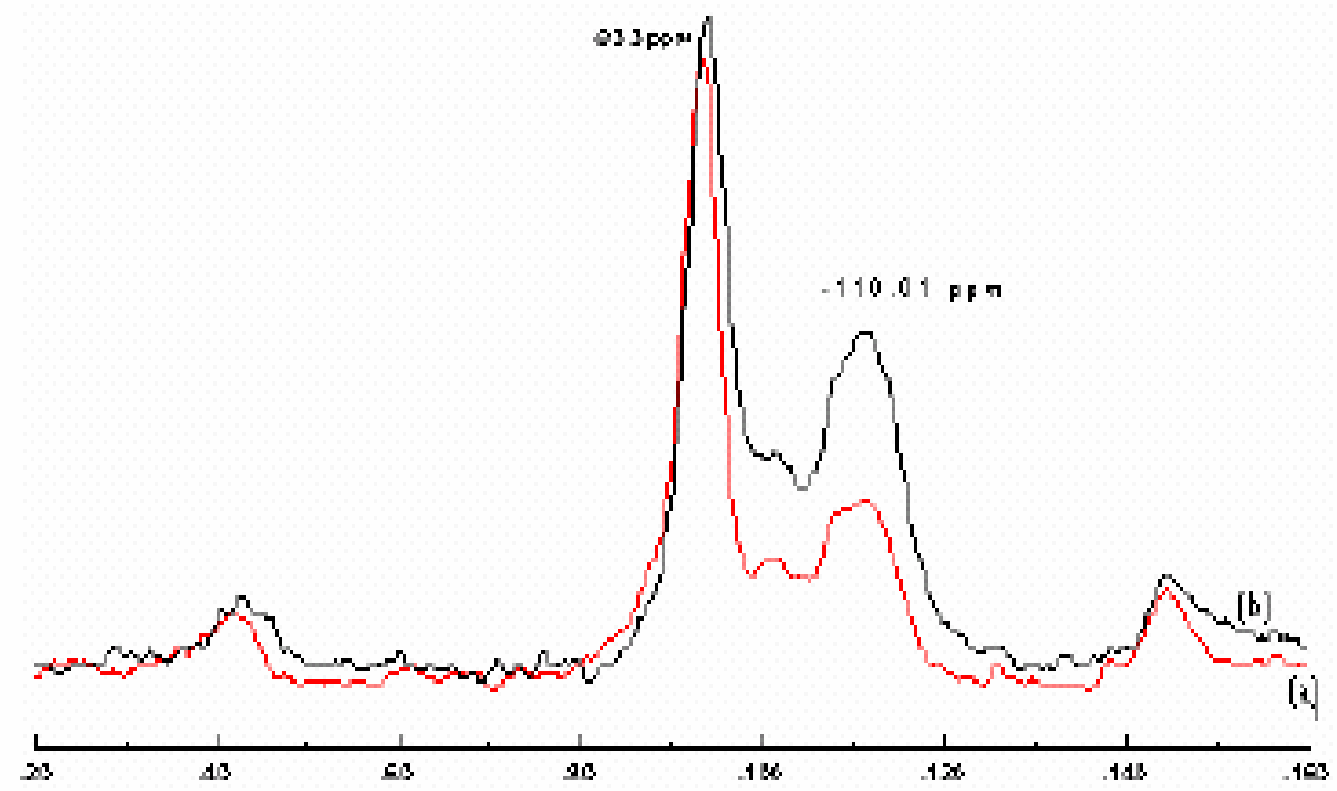

Figure 4. ${ }^{29}$ Si MAS NMR spectra of (a) "Raw-Maghnite" and (b) "H-Maghnite 0.25M"

\section{Polymerization and products characterization}

The results of experiments of THF with phthalic anhydride polycondensation induced by " $\mathrm{H}$ Maghnite $0.25 \mathrm{M}$ " proceed in bulk are reported in Table 3. For all these experiments the temperature was kept constant at $40^{\circ} \mathrm{C}$ for 6 hours.

Table 3. Polycondensation of THF with phthalic anhydride induced by the "H-Maghnite $0.25 \mathrm{M}$ "

\begin{tabular}{ccccccccc}
\hline Experiment & {$[\mathrm{THF}]$} & {$[\mathrm{PA}]$} & {$[\mathrm{AA}]$} & $\begin{array}{c}\text { "H-Maghnite } \\
0.25 \mathrm{M} \text { " }(\%)\end{array}$ & Yield \% & $\mathrm{Mn}$ & $\mathrm{Mw}$ & $\mathrm{Mw} / \mathrm{Mn}$ \\
\hline 1 & 10.75 & 5.67 & 1.28 & 10.0 & 28.32 & 513 & 2637 & 5.14 \\
2 & 10.75 & 5.67 & 1.28 & 2.5 & 8.25 & 582 & 3271 & 5.62 \\
3 & 10.75 & 5.67 & 0.19 & 2.5 & 5.32 & 638 & 3879 & 6.08 \\
\hline
\end{tabular}

[PA]: Phthalic anhydride

[AA]: Acetic anhydride

\section{Effect of "H-Maghnite 0.25M" proportion}

We can see from Table 3 that, the conversion increases with increasing "H-Maghnite 0.25 M" proportion (experiments 1,2). This lead was followed up by a serie of deeper experiments in which the conversion with the time has been observed at various amounts of catalyst. Table 4 and Figure 5 show that increasing the "H-Maghnite $0.25 \mathrm{M}$ " amounts yielded higher conversions. This phenomena is probably the result of number of "initiating active sites" responsible of inducing polymerization, this number is prorata to the catalyst amount used in reaction. 
Table 4. Conversions with time for $10.75 \mathrm{~mol} / \mathrm{l}$ of THF, $5.67 \mathrm{~mol} / 1$ of phthalic anhydride, $0.19 \mathrm{~mol} / 1$ of acetic anhydride and the amounts of $\mathrm{H}$-Maghnite $0.25 \mathrm{M}$ were: a) $2.5 \%$, b) $5 \%$, c) $10 \%$

\begin{tabular}{ccccccc}
\hline & \multicolumn{7}{c}{ Time(hours) } \\
\cline { 2 - 7 } Yield(\%) & 1 & 2 & 3 & 4 & 5 & 6 \\
\hline $\mathrm{a}$ & 0.81 & 1.12 & 2.34 & 3.42 & 6.98 & 8.25 \\
$\mathrm{~b}$ & 2.93 & 3.15 & 5.08 & 6.72 & 13.24 & 18.15 \\
$\mathrm{c}$ & 3.46 & 4.85 & 9.14 & 12.67 & 19.42 & 28.32 \\
\hline
\end{tabular}

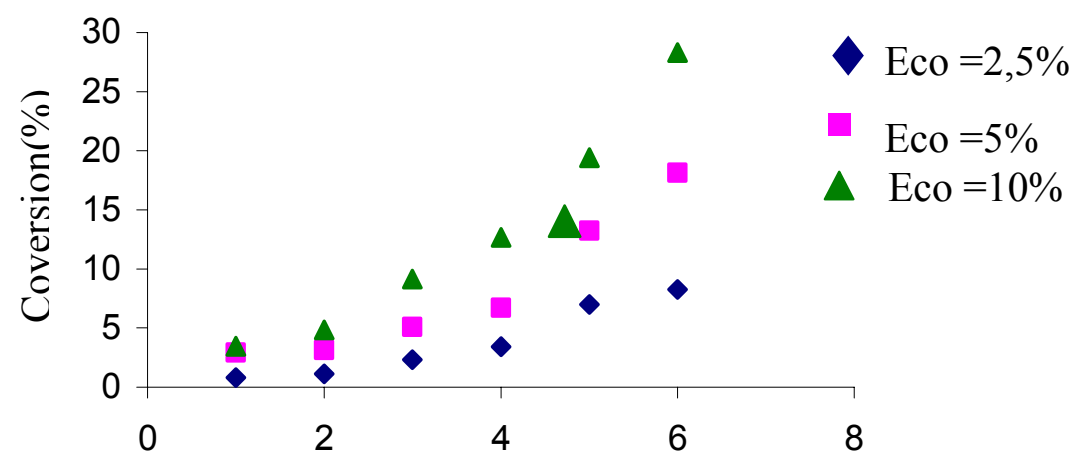

Time (hours)

Figure 5. Effect of catalyst proportion upon the conversion.

\section{Effect of acetic anhydride proportion}

The addition of acetic anhydride to the mixture creates ends of chains unable to take part in polyesterification, and consequently the problem of reproducibility of molecular weight does not exist, which will allow to have a stable polymer.

Data in Table 3 show that the conversions increase with increasing acetic anhydride proportion (Experiments 2, 3). This result is due to multiplication of active centers. However the molecular weight increase with reduction acetic anhydride proportion. This result is due to increasing of methyl groups in extremities of chains who block chains of polymer in growth.

This lead was followed up by a series of deeper experiments in which the conversion with the time has been observed at two amounts of acetic anhydride. Table 5 and figure 6 show that increasing the acetic anhydride amounts yielded higher conversions. 
Table 5. Conversions with time for $10.75 \mathrm{~mol} / \mathrm{l}$ of THF, $5.67 \mathrm{~mol} / \mathrm{l}$ of phthalic anhydride, $2.5 \%$ of $\mathrm{H}$ Maghnite $0.25 \mathrm{M}$ and the amounts of acetic anhydride were: a) $0.19 \mathrm{~mol} / \mathrm{l}, \mathrm{b}) 1.28 \mathrm{~mol} / \mathrm{l}$.

\begin{tabular}{ccccccc}
\hline & \multicolumn{7}{c}{ Time } \\
\cline { 2 - 7 } Yield $(\%)$ & 1 & 2 & 3 & 4 & 5 & 6 \\
\hline & 0.81 & 1.12 & 2.34 & 3.42 & 6.98 & 8.25 \\
& 2.85 & 3.92 & 5.17 & 9.76 & 13.12 & 17.23 \\
\hline
\end{tabular}

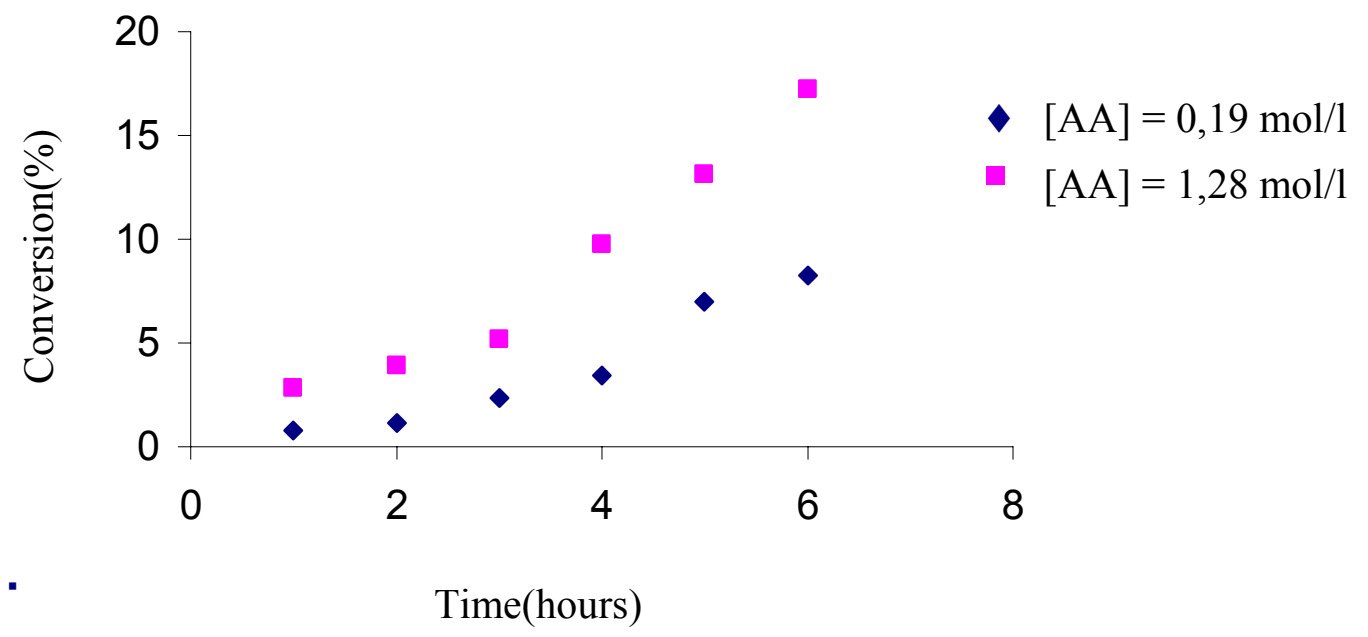

Figure 6. Effect of acetic anhydride proportion upon the conversion.

\section{Characterization of products}

An investigation was devoted to the analysis of the polymer from experiment 2 in Table 3 by ${ }^{1} \mathrm{H}$ NMR spectroscopy at $300 \mathrm{MHz}$ (Table 6, Fig7).

Reaction:

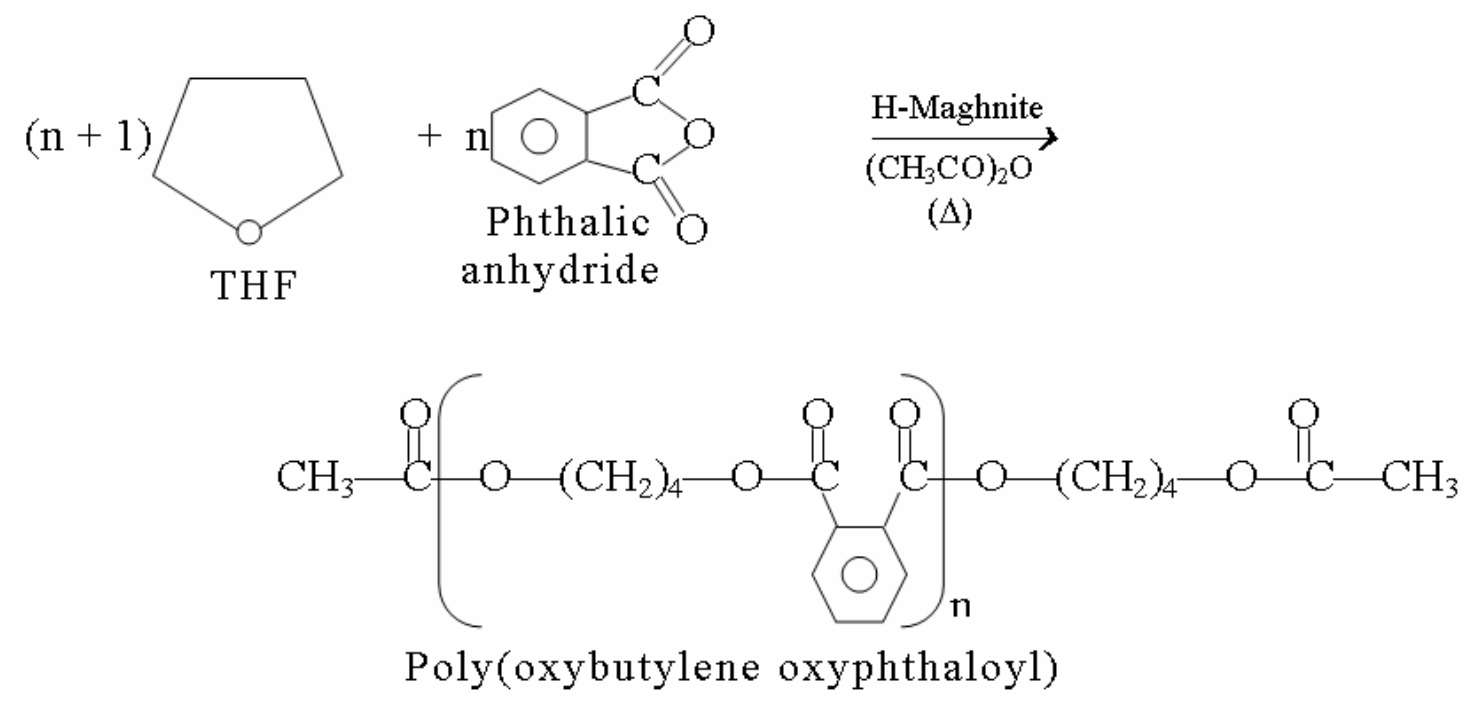


Table 6. Results of products analysis by ${ }^{1} \mathrm{H}$ NMR spectroscopy

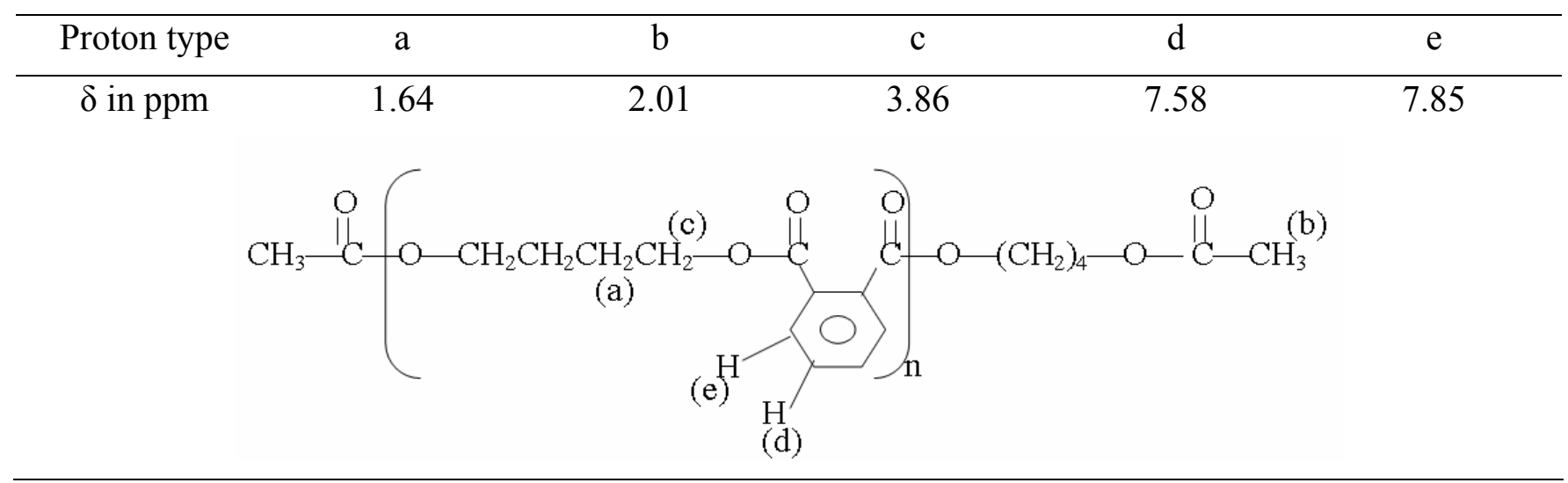

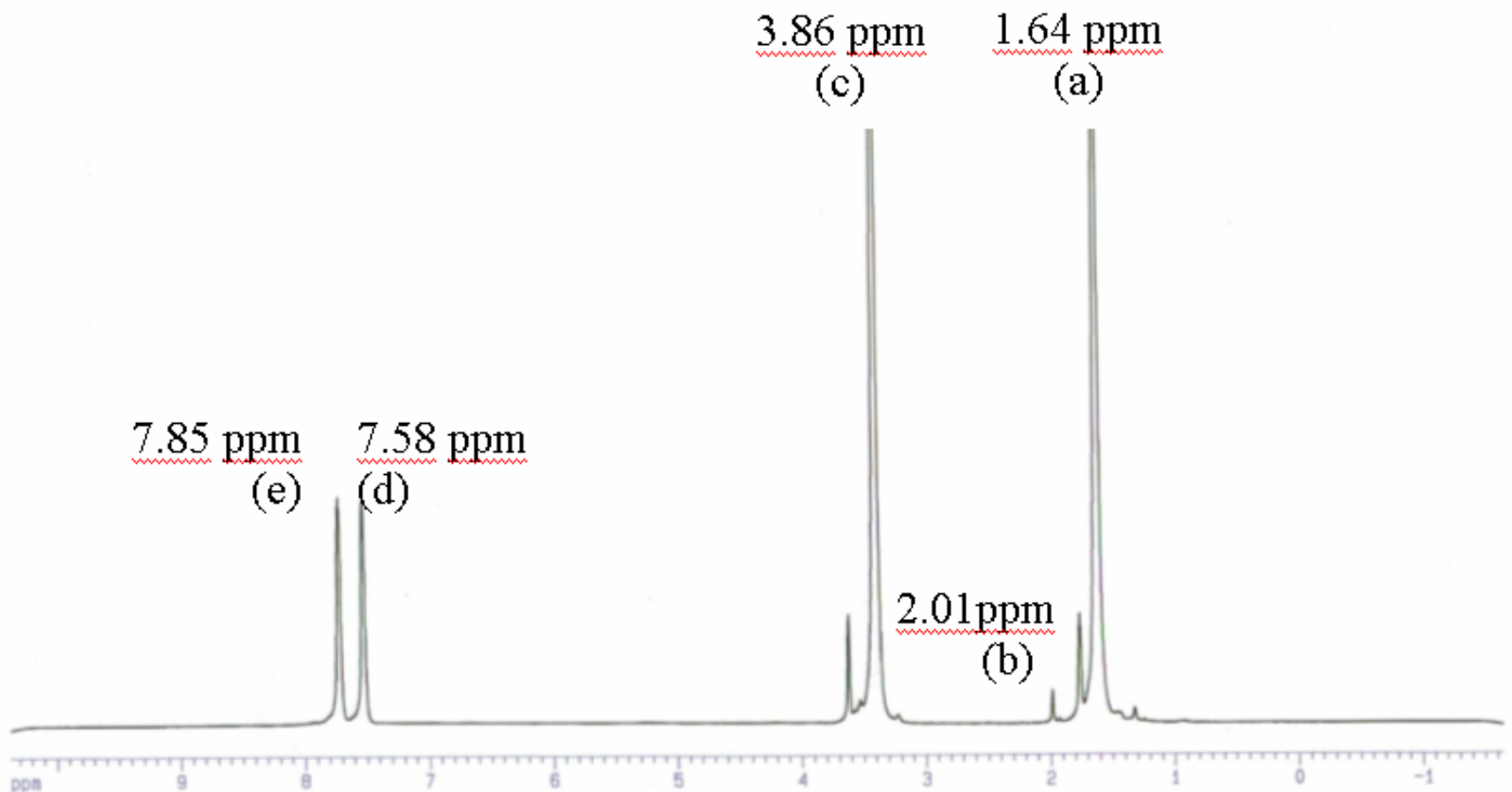

Figure7: ${ }^{1} \mathrm{H}$ NMR spectra of poly(oxybutylene oxyphthaloyl) product of experiment 2 in table 3.

According to the work published by Espartero and Rashkov [14], Khalid et al [15], ${ }^{1} \mathrm{HMNR}$ spectroscopy at $300 \mathrm{MHz}$ (Solvent deuterated THF)(Fig7) showed different peaks, the methyl groups of the main chain at $2.1 \mathrm{ppm}$, the $\beta$ methylene groups at $1.64 \mathrm{ppm}$, the $\alpha$ methylene groups at $3.86 \mathrm{ppm}$, and aromatic groups at $7.58 \mathrm{ppm}$ and $7.85 \mathrm{ppm}$.

\section{Mechanism of the reaction}

Polycondensations proceed by successive reactions between the functional groups of the reagents.According to the foregoing discussion and the results of product analysis, we may suggest the mechanism below for the resulting reaction of polymerization induced by "H-Maghnite $0.25 \mathrm{M}$ ". 
Protons carried by montmorillonite sheets of "H-Maghnite $0.25 \mathrm{M}$ " induced the polymerization, these montmorillonite sheets take place as counter-anions.

The first stage is the protonation of acetic anhydride.

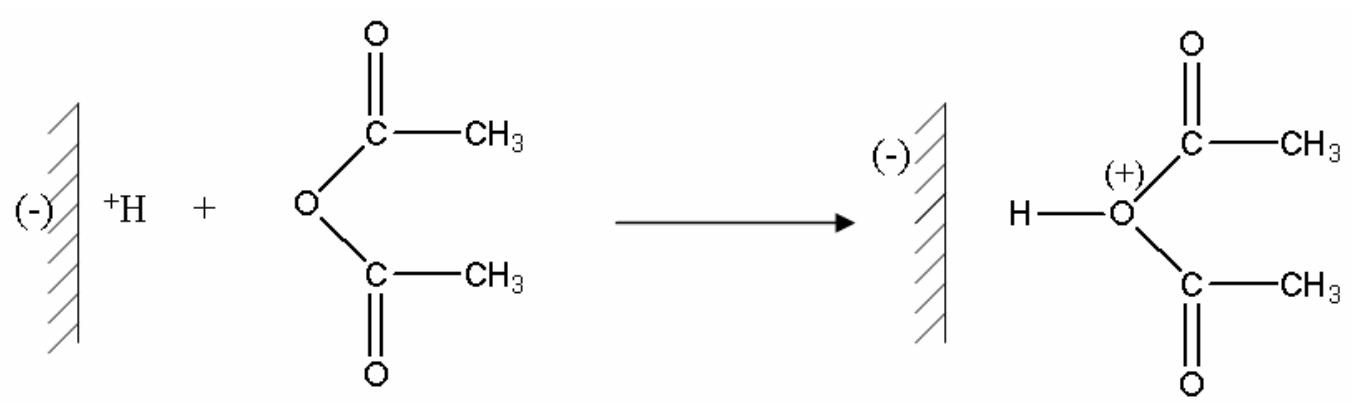

Then a molecule of THF attacks in a nucleophilic way protonic acetic anhydride.<smiles>CC(=O)O[GeH3]</smiles>

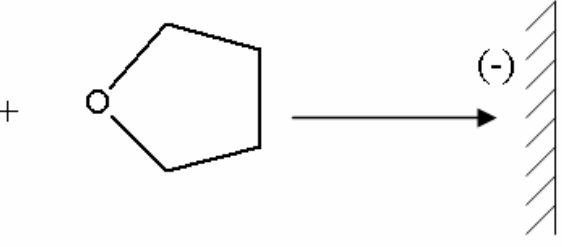<smiles></smiles><smiles>CC(=O)O</smiles>

The formed ions oxonium take place in the vicinity of the counter-anion carried by montmorillonite sheets, and then there is a nucleophilic attack of the oxygen of phthalic anhydride on the carbon located in alpha of oxygen charge carrier positive of the chains in growth.

$(-)$<smiles>O=C(C=CC1CCCCC1)[O+]1CCCC1</smiles><smiles>O=C1OC(=O)c2ccccc21</smiles>

$(-)$<smiles>CCOC(=O)c1ccccc1C(=O)OC(C)(C)C</smiles>

The next stage is a nucleophilic attack of the oxygen of the THF on carbon-cation of the chains in growth. 


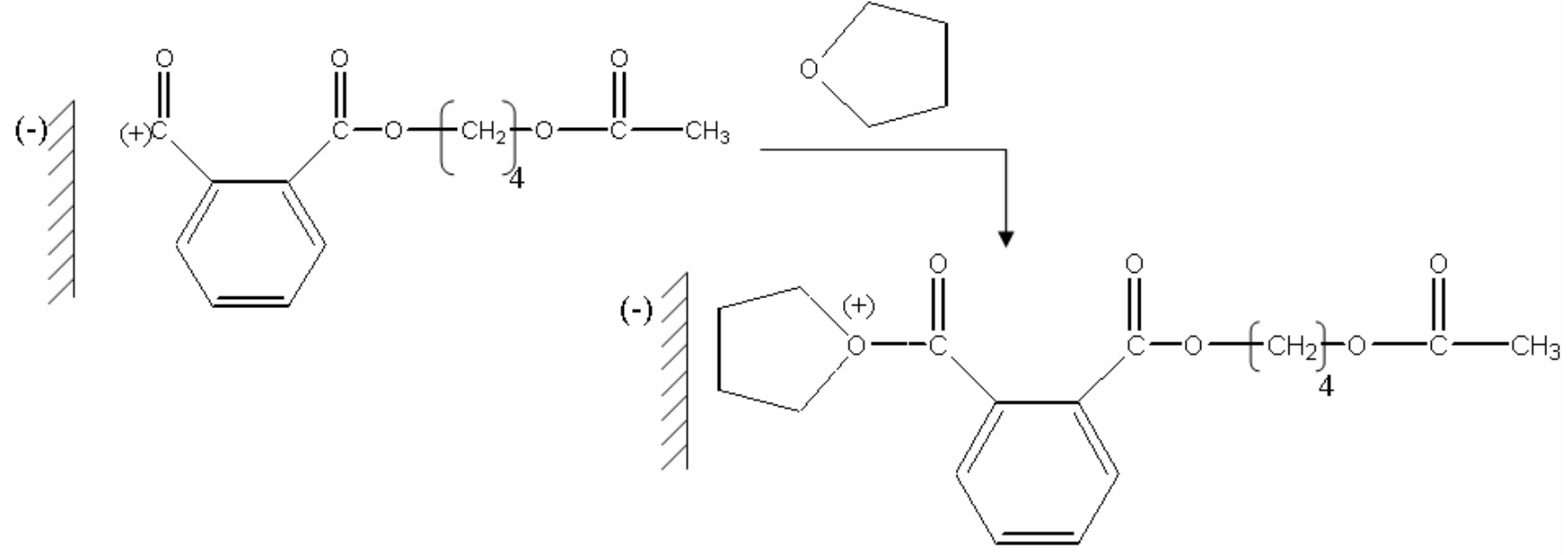

Then we have successive additions of the phtalic anhydride suivue of the THF

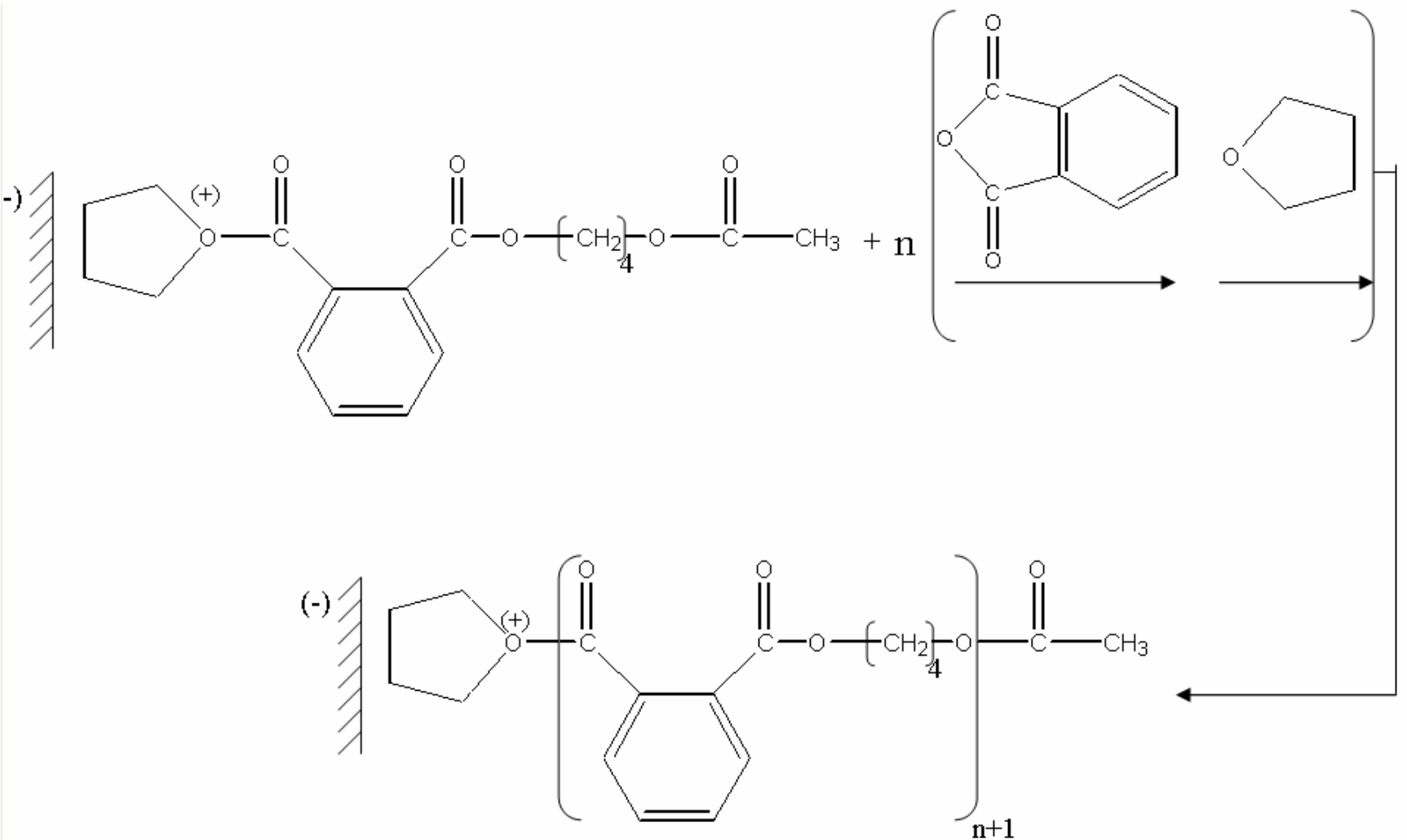

The presence of the groupments acetate at the two ends of the chain was clearly identified by ${ }^{1} \mathrm{H}$ NMR. Therefore, the last stage will be a nucleophilic attack of the oxygen of the acetic acid formed in the first stage which results from the protonation of acetic anhydride on the carbon located in alpha of oxygen charge carrier positive of the chains in growth. 


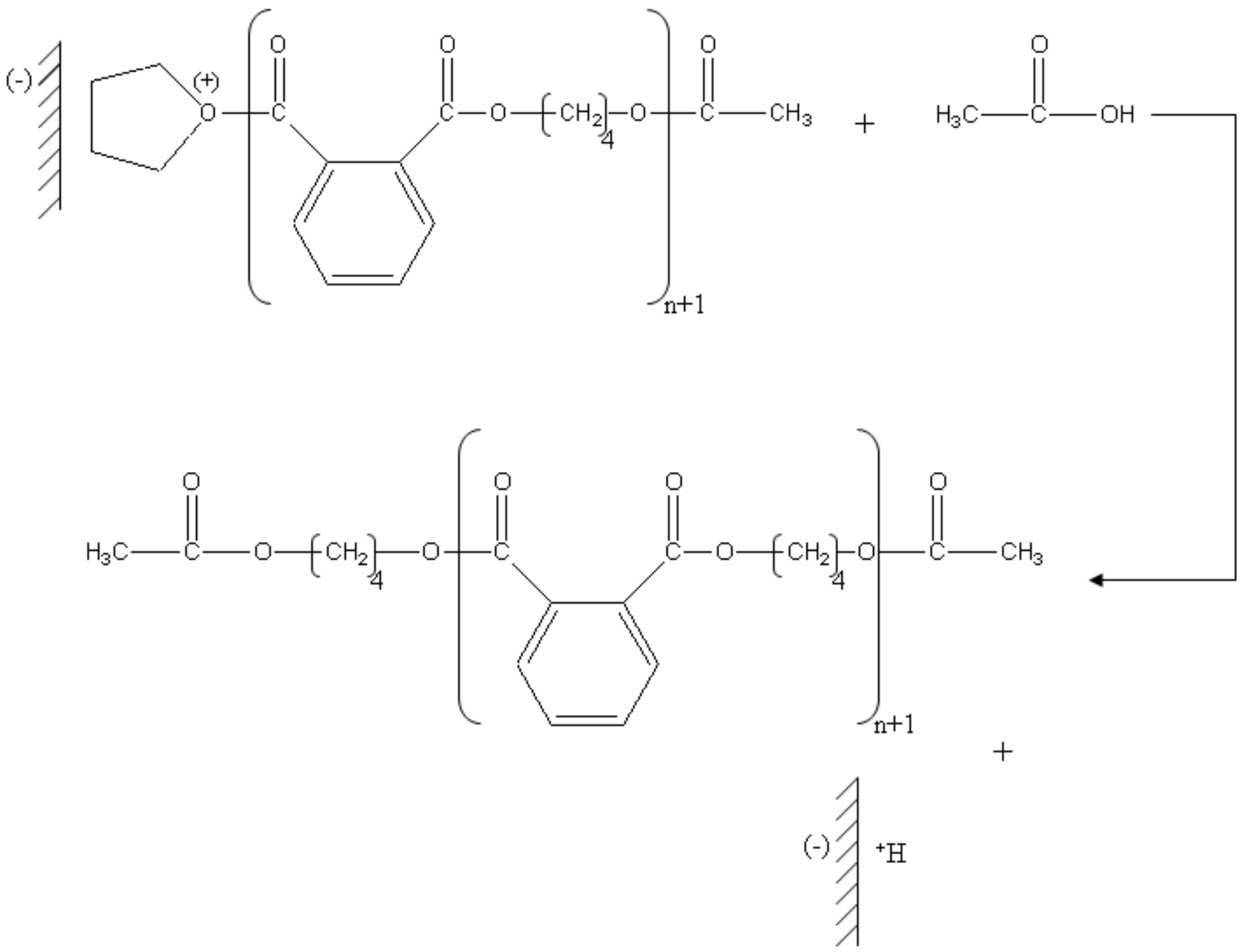

\section{Conclusion}

The present work shows that the preparation of poly(oxybutylene oxy phthaloyl) can be induced in heterogenous phase by proton exchanged montmorillonite clay called "H-Maghnite" and using tetrahydrofuran as a source of an oxybutylene part in the polymer in the place of butan 1,4 diol which is one of the biggest problems with this reaction. Poly(oxybutylene oxyphthaloyl) was produced accordingly by an easy-to-handle procedure in one batch process. This new chemistry will be explored deeply in forthcoming work.

\section{References}

1. Thomas, C.L.; Hickey, J.; Stecker,G. Ind. Eng. Chem. 1950, 42, 866.

2. Kaplan, H. U.S.Patent. 3287422, 1966.

3. Hojabri, F.; J. Appl. Chem. Biotechnol. 1971, 21, 87.

4. Ballantine, J.A.; Davies, M.; Purnell, H. Chemical conversions using sheet silicates: novel interlamellar dehydrations of alcohols to ethers and polymers. J. C. S. Chem. Comm. 1981, 427428. 
5. Odian, G. La Polymérisation: Principes et Applications; Ed.Technica: New York, 1994; pp222226.

6. Breen, C.; Madejovà, J.; Komadel, P. J. Mater. Chem. 1995, 5, 496-474.

7. Farmer,V.C. In Infrared Spectra of Minerals, V.C. Farmer, Ed.; Mineralogical Society: London, 1974, p.331.

8. Moeke, H.H.W. In Infrared Spectra of Minerals, V.C. Farmer, Ed.; Mineralogical Society: London, 1974, p.365.

9. Madejovà, J.; Bednànikovà, E.; Komadel, P.; Cicel, B. In Proc.11th Conf. Chem. Miner. Petrol. Ceske Budéjovica 1990; J. Konta, Ed; Charles University: Prague, 1993; p. 267.

10. Komarneni, S.; Fyfe, C.A.; Kennedy, G. J.; Strobhl, H. J. Am. Ceram. Soc. 1986, 69, 645.

11. Samajovà, E.; Kraus, I.; Lajcàkovà, A. Geol. Carpath. Ser. Clays. 1992, 42, 21.

12. Thompson, J.G. Clay Miner. 1984, 19, 169.

13. Tkàc, I.; Komadel, P.; Müle, D. Clay Miner. 1994, 29, 11.

14. Espartero, J.L.I.; Rashkov, M. Vert. Macromol. 1996, 29, 3535.

15. Khalid, A. M.; Thakur, R.T.; Kean, E.S. Hal. Macromol. 1997, 30, 2422.

(C) 2003 by MDPI (http://www.mdpi.org). Reproduction for noncommercial purposes permitted. 